\title{
Közel-Keleti országok nagyvárosainak közlekedési rendszere
}

\section{Transportation system of major cities in the middle} east

\author{
B. KASZA, Á. UNGVÁRAI, J. LIPTÁK-VÁRADI \\ University of Debrecen, Hungary, kaszabius01@gmail.com \\ University of Debrecen, Hungary, ungvarai@eng.unideb.hu \\ Prince Sultan University, Saudi-Arabia, jvaradi@psu.edu.sa
}

\begin{abstract}
Absztrakt. A közlekedés minősége lényeges hatással van mindennapjainkra, és bolygónk jövőjére egyaránt. Különös érdeklődéssel figyelhetjük meg a Közel-kelet nagyvárosait, ahol a közlekedési kultúra egész más irányt vett, mint Európában. E városok kialakulásukban, történelmi struktúrájukban kivételesek, mint a világ egyéb városai. Egy ilyen nagyvárosra fókuszál jelen cikk: Rijád, egy 6 milliós világváros kerül elemzésre, mint az arab világ tipikus autóalapú települése. A vizsgálathoz összehasonlítás is készült 4 várost alapul véve: Dubai, mint Rijádhoz hasonló adottságú város; Amsterdam, mint fejlett, zöld szemléletmódot megtestesítő város; Budapest, mint hazai nagyváros valamit Debrecen, mint hazai kisváros. Ezekböl tanulságokat levonva igyekszünk értékelni Rijád forgalmi rendszerét valamint javaslatokat is teszünk.
\end{abstract}

Abstract. The quality of transportation has a great effect on the quality of our everyday life and the future of our planet. In contrary to Europe, transportation culture of the big cities in the Middle East region has grown fully different way. These Middle Eastern cities tend to have a different historical, traditional and structural background compared to other cities all around the world. One of these big cities is in the focus of our paper: Rijad, with 6 million inhabitants is the archetypal car dominated city of the Arabic world. We also elaborated a comparison to 4 other cities: Dubai as a city similar to Rijad, Amsterdam as a city with a modern green attitude, Budapest as a metropolitan city in Hungary and last but not least Debrecen which is a Hungarian city with moderate population. As a lesson learnt, we try to give some possibilities and outlooks for Rijad, in order to improve the structure of transportation.

\section{Bevezetés}

Az 1700-as évek végére a technikai forradalom elérte a motorizáció kialakulását. Az autó, megszületését követően futótűzként terjedt. Ezek nagy hatással voltak a kereskedelem fejlődésére és az lehetővé tették az emberek egyéni mozgásait is. Mindez egyre több közösségi járatot indukált, amelyhez elengedhetetlenné vált az infrastruktúra arányos modernizációja. A népességnek ez az állandósult növekedése mai napig nem fejeződött be. A különböző gazdasági, társadalmi és politikai 
hatások különböző városi struktúrákat eredményeznek az eltérő lehetőségek, ismeretek, éghajlati és egyéb tényezők miatt. Ennek egyik érdekes példája az, hogyan hatott a kőolaj robbanásszerű gazdasági erővé válása a Közel-keleti országok városfejlődésére. A kőolaj felfedezése rohamos gazdasági fejlődést idézett elő ebben a térségben, ami a városok extrém sebességű fejlődéséhez vezetett, vezet. Ezekben az országokban (például Szaúd-Arábia, Kuvait, Egyesült Arab Emírségek) a városok kialakulása, a technikai forradalom, a motorizáció szinte gyorsított felvételként játszódott le. Autóalapú városok kialakulása volt megfigyelhető.Az fejlődésnek az előnyök mellett számos hátrányos következményei is vannak. A káros anyag kibocsátás a mozgásszegény életmódból adódóan, a zajszennyezés, és sok egyéb más negatívumot köszönhet a társadalom a gépjárművek térnyerésének. Ezt tetőzve a globális környezetszennyezés, az üvegházhatás és a klímaváltozás is érezteti hatását, melynek tetemes részét a közlekedés okozza, azon belül is az autózás.

Ezen problémákat és azokra való lehetséges megoldásokat ismerteti a cikk. A Közel-keleti országok autó alapú forgalmi rendszerének feltárásához egy Közel-keleti várost elemzünk, Szaúd-Arábia fővárosát Rijádot.

\section{Esettanulmány: Rijád}

Szaúd-Arábia fővárosa, Rijád az Arab-félsziget közepén a Najd-régióban három vádi (al-Bathá, Hanifa és Ajszan) által közbezárt fennsíkon fekszik. Nagyon száraz, az év nagy részében forró a klíma, a legmelegebb hónapokban $48-49^{\circ} \mathrm{C}$ is lehet a napközbeni hőmérséklet. Szaúd-Arábia egyben az iszlám vallás központja. A középkori város fejlődése, létezése bizonytalan, de a 19. századra lakott terület vált. A népesség növekedése rohamos volt. Az első népességi adat még gyér, a 19. századból való: 7500 embernek adott otthont. Az 1950-es években elindult a változás: már 120 000, még 30 év elteltével 1,3 millió, mára pedig 6 millió fő́t számlál a népesség. [2.]

Szaúd-Arábia az ipari forradalom, motorizáció és a nyersanyag birtoklásának következtében hatalmas olajkitermelő és értékesítő vidék. Mind máig az ország bevételének 75 százalék származik az olajból. [3.]Szaúd-Arábia társadalmi berendezkedése nagyon összetett. A szaúdi állampolgárok mellett nagyszámú külföldi él az országban. A lakosság túlnyomó többsége napi autóhasználó. A település ezért tipikus példájává vált az autóalapú városoknak, ezzel járó előnyével és hátrányával egyaránt rendelkezik.

\subsection{Az autóalapú Rijád közlekedésének ismertetése}

A városnak a növekvő gépjárműforgalomból adódóan több meglepő sajátossága van. Városi tömegközlekedéssel egyáltalán nem rendelkezik, bár egy nagyszabású metróépítés napjainkban épp folyamatban van: hat vonal épül egyszerre. Mikor Szaúd-Arábiáról van szó a női jogok kérdése is fontos feladat, a mi esetünkben is , mivel ezen sajátosság nagy hatással van a városi forgalom átalakulására. A nők nem vezethetnek gépjárművet Szaúd-Arábiában. A hölgyek sofőr által képesek hosszabb utat megtenni, ami érdekében mindig rendelkezésükre kell, hogy álljon egy sofőr személygépkocsival, aki így többszörös távot autózik a célok között. Mindemellett a térség klímájából is adódnak gondok, nyáron a hőmérséklet elérheti az $50^{\circ} \mathrm{C}$-ot. Ez szintén kedvezett az autóközpontúságnak: az emberek többsége inkább a háztól-házig szállítást választja, hiszen ezt a meleget nehezen bírnák akár egy-egy átszállás időtartamán belül, illetve a gyalogos utat a megállóig és a leszállás után. 
A fejlett országokban a levegőszennyezés - gázkomponenstől függően - 40-80\%-áért felelős a közlekedés. Jórészt a közlekedésből származnak az egészségre különösen káros, toxikus rákkeltő szennyező anyagok.[4.] Ebben a közegben élő emberek egészségügyi mutatói jóval alacsonyabbak egy, más szegmensből vett példáétól. Ismert, hogy környezet- és egészségvédelmi szempontból városi viszonyok közt legoptimálisabb a gyalogos és kerékpáros közlekedés lenne, de az ilyen forgalomnak Rijádban nem adottak a lehetőségei. A nők autóvezetés mellett nem is kerékpározhatnak. A járdák nincsenek egybefüggően kiépítve. Ahol mégis, ott a több sávos autóutak elveszik a biztonság alapvető érzetét.A város problémáinak részletes kifejtése egy, 2016-ban készült TDK dolgozatban található meg. [1]

\section{2. Összehasonlítás más városokkal}

A megoldásmenet lehetséges változatainak kidolgozásában több, már érett illetve jelenleg is fejlődő városnak a közlekedési problémákra adott válaszait használtuk fel. Felmérésre került:

- Dubai - mint Rijádhoz hasonló adottságú város;

- Amsterdam - mint fejlett, zöld szemléletmódot megtestesítő város;

- Budapest - mint hazai nagyváros; valamint

- Debrecen - mint hazai kisebb város.

Dubai - hasonlóan Rijádhoz - a kőolaj miatt lett gazdasági nagyhatalom. Felismerve azonban, hogy ez a gazdagság nem tart örökké, elkezdték sokrétűbbé tenni: turisztikai és közlekedési csomóponttá fejlesztették a várost. Látványos építkezések kísérték ezt a változást, és a közlekedést sem hagyták ki. A közösségi közlekedésnek minden formája megtalálható Dubaiban. Bár a gyalogos közlekedés itt sem ajánlott, számukra nem adatik meg elég figyelem és biztonság.

Amsterdam területe már 4600 éve lakott, hatalmas gazdasági és kereskedelmi hagyományokkal rendelkezik, tagja a híres Hansa-szövetségnek. A motorizáció Amsterdamot sem kerülte el, a második világháború után gyorsan zsúfolttá váltak a szűk utcák. A lakosság az addigi életmódtól eltérően a keskeny járdákra kényszerült. Ebben az időben született meg a változtatni akarás érzése. Az 1970-es években a kőolajválság is nyomást gyakorolt a kormányra, mely inkább a kerékpáros infrastruktúra irányába terelte a jövőt. Ez máig meghatározza az emberek gondolkodásmódját, mára gyerekeik is ilyen szemléletben nevelkednek. A gondolkodás meghozta gyümölcseit: a népegészség javul, a zsúfoltság csökken, szmog riadóra nem kell számítani.

Budapest és Debrecen esete hasonló, mindkettő hazai város. A motorizáció Magyarországon később robbant be, az 1970-es években indult el, és igazi térnyerése a rendszerváltásra tehető. Amikor az embereknek hirtelen lehetőségük nyílt autót vásárolni, a forgalmi terhelés is ugrásszerűen nőni kezdett, ugyan azokkal a problémákkal, amik nyugaton már rég gondot okoztak. A Budapesti közlekedésre jellemző, hogy az egyéni gépjárművet használók aránya mindmáig egyre nő. Arányuk még ugyan mindig nem érte el a nyugati szintet, de a trend olyan, mint Hollandiában az 1960-as, 70-es években. A gondolkozásmód megérett a változásra. Debrecen nagyon jó példája azoknak a kisvárosoknak, ahol még nincs kiforrott megoldásmenet az autósforgalom visszaszorítására, próbálkozások vannak, amelyek több-kevesebb sikerrel járnak. A közlekedésben a reggeli és a délutáni forgalom már rég meghaladta a kellemes szintet. Az autózásnak hatásos szemléletbeli változása viszont nem következett be. 


\section{3. Értékelés és megoldási stratégiák}

A robbanásszerű népesség növekedés, a bevándorlási arány, az olaj olcsó és közvetlen elérése lehetővé tette azt, hogy a népesség minden esetben a gépjármű közlekedést részesítse előnyben. Mindenki ebben a gondolatban él, nem is igazán ismer mást. Ebből kiindulva bármely megoldási javaslat egy nagyon összetett kérdés, függ a politikai és gazdasági döntésektől egyaránt.

A térség megfejtésének menete egyedi kihívásokat tartalmaz, melyeket részletesen a korábban is említett 2016-os TDK dolgozatban tárgyalunk [1]. Kiemelve ezek közül néhányat: az időjárási viszonyok megoldására szükség lenne több árnyékot biztosító növényzet telepítésére, amelyek az építendő járdák és kerékpárutak mellett biztosítanák a kellemesebb hőmérsékletet a kritikus évszakokban. A gyalogos közlekedést fontos lenne biztosítani legalább a lakóövezetekben. A közösségi közlekedés fejlesztését és járatszámainak növelését követően az átszállási pontokon légkondicionálóval lehetne biztosítani az elviselhető hőmérsékletet, mindemellett a Dubaiban már bevált légkondicionált buszmegállókat jól alkalmazhatnák, napelemes áramellátással. A nők joga a gépjárművezetéshez is segítene, ezzel a felesleges sofőringázások kimaradnának. P+R parkolókat kellene a belváros peremén létrehozni, ahová a közösségi közlekedést belátható időn belül el lehetne juttatni. A túlságosan alacsonyan tartott olaj ára buzdító hatású. Ennek elkerülése érdekében külön adórendszert kellene kifejleszteni az autóhasználók kárára, amely rögtön észrevehető visszaesést okozna. Amszterdam példájából tanulva a belváros egyes szegmensein tiltani kellene a gépjárművel való közlekedést. A népesség növekedésével járó problémák tudatos orvoslására jó példa a bécsi Seestadt Aspern városrész. A betelepülni vágyókat kiépített közösségi közlekedés fogadja, ebből kifolyólag nem kényszerülnek olyan zsákutcákba, mint a kizárólagos gépjármühasználat. [5.] A klíma adta nehézségek újragondolásából sok megoldás születhet, amely hosszú távon mindenképp megérné.

Ezek a vizsgálódások, elmélkedések minden városnak létfontosságúak lennének, mivel útmutatásul szolgálhatnak a buktatók elkerülésére, zsákutcák feltárására. Hosszú távon Debrecennek is értékes tanulságok vonhatóak le, hogy egy lehetőleg zöld, fenntartható irányt vegyen a város infrastruktúrájának kialakítására.

\section{Hivatkozások}

[1] Kasza Bianka: Közel-Keleti országok nagyvárosainak közlekedési rendszere, konzulensek: Ungvárai Ádám, Dr. Lipták-Váradi Julianna, TDK Dolgozat, Debreceni Egyetem Műszaki Kar, 2016.

[2] Wikipedia: Riyadh https://en.wikipedia.org/wiki/Riyadh hozzáférés ideje: 2016.10.25.

[3] Andrew B Clarke, Stephen Luke, Georg Vitt, Atef M. Garib Ph.D. : The context for public transport development in the Gulf states : unique challanges and perspectives

[4] Mészárosné Kis Ágnes - Lukács Pál A közlekedési környezetvédelem helyzete és jövőbeli alakulása 1999-től 2020-ig; ;ttp://www.nih.gov.hu/letolt/kutat/tep/kozlek/meszarosne.pdf hozzáférés ideje: 2016.11.01.

[5] http://index.hu/tech/2016/10/31/becs_mellett_epul_a_jovo_varosa/ hozzáférés ideje: 2016.11.17. 